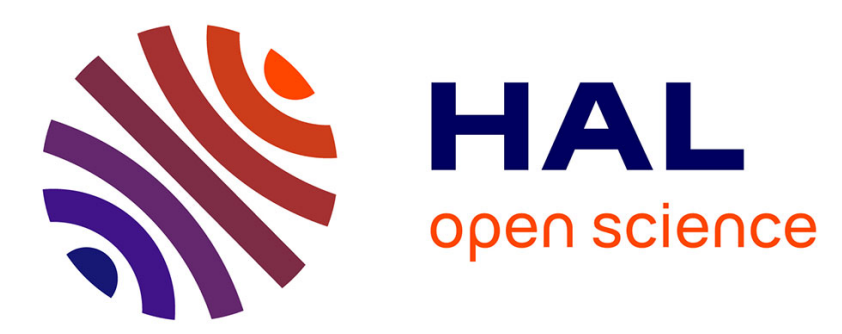

\title{
Prosodic Units and Intonational Grammar in French: towards a new Approach
}

\author{
Elisabeth Delais-Roussarie, Brechtje Post, Hiyon Yoo
}

\section{To cite this version:}

Elisabeth Delais-Roussarie, Brechtje Post, Hiyon Yoo. Prosodic Units and Intonational Grammar in French: towards a new Approach. Proceedings of Speech Prosody, 2020, 10.21437/speechprosody.2020-26 . hal-03098049

\section{HAL Id: hal-03098049 https://hal.science/hal-03098049}

Submitted on 5 Jan 2021

HAL is a multi-disciplinary open access archive for the deposit and dissemination of scientific research documents, whether they are published or not. The documents may come from teaching and research institutions in France or abroad, or from public or private research centers.
L'archive ouverte pluridisciplinaire HAL, est destinée au dépôt et à la diffusion de documents scientifiques de niveau recherche, publiés ou non, émanant des établissements d'enseignement et de recherche français ou étrangers, des laboratoires publics ou privés. 


\title{
Prosodic Units and Intonational Grammar in French: towards a new Approach
}

\author{
Elisabeth Delais-Roussarie ${ }^{1}$, Brechtje Post ${ }^{2}$, Hiyon Yoo ${ }^{3}$ \\ ${ }^{1}$ Université de Nantes, UMR 6310-LLING (France) \\ ${ }^{2}$ University of Cambridge, Phonetics Laboratory, Faculty of MMLL (UK) \\ ${ }^{3}$ Université de Paris, UMR 7110-LLF (France)
}

\section{Elisabeth.delais-roussarieduniv-nantes.fr, bmbp2@cam.ac.uk, yoo@linguist.univ-}

\section{paris-diderot.fr}

\begin{abstract}
In most studies on French prosody, two or three distinct levels of constituency above the word are assumed: the accentual phrase, the intermediate phrase and the intonational phrase. While there is considerable agreement on the definition of the accentual phrase, there is much controversy over the two other levels.

In this paper, we will argue for a new definition of the intermediate phrase. Our proposal will depart from previous work in two ways. First, we will clarify the extension and status of the intermediate phrase (or phonological phrase) in such a way as to consider it essentially as a metrically-driven prosodic unit. Second, a distinction will be made between this metricallydriven phrase and two types of intonational phrases on the basis of the intonational contours occurring at their right edge.

This proposal, which accounts for phrasing and intonation contour choice at the underlying phonological level, is based on the analysis of utterances extracted from experimental studies and corpora, focussed on (a) the inventory and possible realisations of the contours at the right edge of these phrases, and (b) their relation with the morpho-syntactic and semantic structures.
\end{abstract}

Index Terms: prosodic structure, intonation, interface phonology/syntax, intermediate phrase, intonational phrase

\section{Introduction}

In most studies dedicated to prosodic phrasing and intonation, an utterance is considered to be segmented into hierarchically organized prosodic constituents (see, among others, [1], [2], [3], [4] and [5]). For French, three levels of structure are usually recognised in prosodic models developed within the autosegmental-metrical framework (AM model), see, among others, [6], [7], [8] and [9]:

- the Accentual Phrase or AP, also called prosodic word [10] or phonological phrase ([6]);

- $\quad$ the intermediate phrase or ip ([7] and [9]);

- the Intonational Phrase or IP (in almost all models).

Despite some variability observed in the way an utterance can be segmented into APs, as shown in (1), there is considerable agreement on the definition and characteristics of this prosodic unit.

(1) Ces jeunes enfants apprennent à parler le français. a. (ces jeunes enfants) $)_{\mathrm{AP}}$ (apprennent à parler) $)_{\mathrm{AP}}$ (le français $)_{\mathrm{AP}}$

b. (ces jeunes enfants) $)_{\mathrm{AP}}(\text { apprennent })_{\mathrm{AP}}(\mathrm{à} \mathrm{parler})_{\mathrm{AP}}(\mathrm{le}$ français) $)_{\mathrm{AP}}$

'These young children learn to speak French'

Metrically, the AP consists of a sequence of syllables of which the last one is stressed (bearing primary stress). Because of the strong syncretism between accentuation and intonation in French, a rising intonational contour is associated with the primary stressed syllable, and a tonal contour of the form given in (2) is usually associated with every non final AP (see also [8]).

\section{(2) $\mathrm{aL}(\mathrm{Hi}) \mathrm{L} \mathrm{H}^{*}$}

In terms of mapping with the morpho-syntactic structure, the AP is often described as consisting of a content word (verb, noun, adverb) preceded by the function words related to it (preposition, determinant, etc.) and can be derived from the morpho-syntactic structure by means of the alignment constraint Align R Xhead (see, among others, [4], [7] and [10]).

By contrast, there is little agreement on the definition of the intermediate phrase, and to a lesser extent, the Intonational phrase, as some overlap may arise on the extension of these two prosodic domains.

In this paper, by focusing on the intermediate phrase and the tonal patterns that can be observed at its right edge, we will argue for a new way of defining this phrase, and capturing the differences between the ip and the IP. This will shed new light on French prosodic structure and allow us to disentangle metrical from intonational structure.

The paper will be organized as follows. In section 2, we provide a review of the literature in order to describe in which position intermediate phrase boundaries are usually observed. This will lead us to distinguish three distinct types of intermediate phrase. In section 3, after a review of the French tonal inventory, we will present the various tonal patterns and phenomena that can occur at the right edge of the three distinct types of intermediate phrase. On the basis of this, we will argue in section 4 for a new way of defining the various prosodic constituents in French. The proposal made here is based on the analysis of utterances gathered in various French oral corpora as well as experimental data sets used for previous studies.

\section{The ip, a problematic level of phrasing}

As mentioned, while there is relative strong agreement on the extension and properties of the accentual phrase, there is more 
controversy with respect to the intermediate phrase and, to a lesser extent, the intonational phrase. Some authors do not even recognise a level of structure equivalent to the ip (see, among others, [6] and [10]). A review of the literature yielded a set of utterances which appeared to require reference to the intermediate phrase as an additional level of structure (see, among others, [8] and [9]). The analysis of these sample sentences leads us to distinguish three types of intermediate phrases on the basis of the location of the boundaries.

Before describing each class of $i p$, it is important to bear in mind that, in addition to intonational cues (partial resetting, for instance [9]), three independently motivated types of information are usually assumed to influence prosodic boundary placement and to play a role in the evaluation of the relative strength of the boundary:

- The morpho-syntactic structure, as prosodic phrase boundaries align to designated edges of various syntactic phrases (right or left edge of heads of maximal projections, etc.) according to some studies (see [4], [5] for syntax-prosody mapping expressed in terms of alignment constraints; and [10] for French).

- The information structure, as the topic or the informational focus of an utterance may call for the realization of specific prosodic boundary (see, for instance, the various constraints that account for the alignment of prosodic phrases to topic [11], or focus phrase [12], [13] and [14]).

- The metrical structure, since the size or the metrical structure of a syntactic unit may influence prosodic phrasing and stress/accent placement (see, among others, [6] and [10]). In French, for instance, it has been shown that the size of the accentual phrase is usually limited to six or seven syllables (see, among others, [10] and [15]).

\subsection{The metrically-driven intermediate phrase}

This type of ip consists of long subject NPs as in (3) and (4) extracted respectively from [8] and [9], which includes two or more APs.

(3) Le directeur de l'école ne voulait pas voir le guide des touristes qui attendait à la réception.

$\left[\left\{[\text { le directeur })_{\mathrm{AP}}(\text { de l'école })_{\mathrm{AP}}\right\}_{\text {ip }}\{\text { (ne voulait pas voir })_{\mathrm{AP}}\right.$ (le guide des touristes) $\left.)_{\mathrm{AP}}\right\}$ ip \{(qui attendait) AP $_{\mathrm{AP}}$ la réception) $\left.\left.)_{\mathrm{AP}}\right\}_{\mathrm{ip}}\right]_{\mathrm{IP}}$

'The hotel director didn't want to see the tourist guide who was waiting at the reception'

(4) La mamie des amis de Rémi demandait l'institutrice. $\left[\left\{(\mathrm{La} \text { mamie })_{\mathrm{AP}} \quad(\text { des amis })_{\mathrm{AP}} \quad(\text { de Rémi })_{\mathrm{AP}}\right\}_{\mathrm{ip}}\right.$ $\left.\left\{(\text { demandait })_{\mathrm{AP}}(\text { l'institutrice })_{\mathrm{AP}}\right\}_{\text {ip }}\right]_{\mathrm{IP}}$

'The grandmother of the friends of Rémi asked for the teacher'

ip boundaries are also observed at the end of an object NP in case of double object construction or branching object NP as in

(5) extracted from the Eurom Corpus.

(5) Il réglait le déchargement des casiers sur les chariots des mareyeurs.

$\left[\left\{(\text { Il réglait })_{\mathrm{AP}}(\text { le déchargement })_{\mathrm{AP}}(\text { des casiers })_{\mathrm{AP}}\right\}_{\text {ip }}\{(\right.$ sur les chariots $\left.\left.)_{\mathrm{AP}}(\text { des mareyeurs })_{\mathrm{AP}}\right\}_{i p}\right]_{I P}$

'He was in charge of the unloading of the racks on the carts of the fish wholesalers.'
Interestingly, these intermediate phrases include two or three APs, but never four or more. Moreover, the ip right boundary often aligns with the right edge of a maximal projection, i.e. a branching subject NP, etc. It can thus be seen as equivalent to the major phonological phrase as often defined by the mapping constraint AlignXMax (see, among others, [5], [10] and [12]).

\subsection{The incidental intermediate phrase}

In some studies, an ip boundary is assigned at the right edge of a wide variety of syntactic phrases having a specific informational status (as being topic or frame-setting topic, parenthetical, etc.). This type of ip occur in specific constructions like the ones mentioned in (6).

(6) Constructions with an ip boundary at their right edge

a. Dislocated XP

A Paul, je lui ai donné un livre.

$\left.\left[\left\{(\text { à Paul })_{\mathrm{AP}}\right\}_{\text {ip }}\left\{(\text { je lui ai donné })_{\mathrm{AP}} \text { (un livre }\right)_{\mathrm{AP}}\right\}_{\mathrm{ip}}\right]_{\mathrm{IP}}$

'[To] Paul, I have given him a book'

b. Adjunct and frame-setter:

Chaque lundi, Paul n'est pas là.

$\left[\left\{(\text { Chaque lundi })_{\mathrm{AP}}\right\}_{\mathrm{ip}}\left\{(\text { Paul n'est pas là })_{\mathrm{AP}}\right\}_{\mathrm{ip}}\right]_{\mathrm{IP}}$

'Every monday, Paul is not there'

Quand je vais à Toulouse, je prends toujours le train. $\left[\left\{(\text { Quand je vais })_{\mathrm{AP}} \text { (à Toulouse }\right)_{\mathrm{AP}}\right\}_{\text {ip }}\{$ (je prends toujours le train $\left.\left.)_{\mathrm{AP}}\right\}_{\text {ip }}\right]_{I \mathrm{P}}$

'When I go to Toulouse, I always take the train'

c. Incidental clause:

François, d'après ce qu'on m'a dit, va partir en vacances en Grèce.

$\left[\left\{(\text { François })_{\mathrm{AP}}\right\}_{\text {ip }}\{\text { (d'après ce qu'on m'a dit })_{\mathrm{AP}}\right\}_{\text {ip }}$ $\{\text { (va partir })_{\mathrm{AP}}$ (en vacances)AP (en Grèce) $\left.\left.)_{\mathrm{AP}}\right\} i p\right]_{\mathrm{IP}}$ 'François, as far as I've been told, will go on holiday in Greece'.

In [8] as well as in other studies within the AM model, IPs often coincide with the entire sentence, or with independent clauses, so that detached constituents, often surrounded by commas, are treated as intermediate phrases. Note however that the contours realised at the right edge of these constructions vary greatly (see, among others, [16] and [17]). Despite this variation, the prosodic phrases derived from these constructions usually cannot 'restructure with any following material, even when they are very short' (see [16]). This is why some authors argued that these constructions call for the realisation of an intonational phrase boundary at their right edge (see, among others, [18] and [19]). To sum up, the variability in the way the contours are realised and the impossibility of restructuring can explain why some controversies exist on the strength of this boundary: intermediate phrase or intonational phrase?

\section{3 ip boundary and informational focus}

When IPs coincide with entire sentences or independent clauses (as in [8]), initial constituents are treated as an ip, but they could be used as a full elliptical clause/ proposition, as shown in (7), these examples being extracted from [8].

(7) a. A: Elle est enceinte de qui ?

'Whose baby is she pregnant with?'

$\mathrm{B}$ : de son mari, pardi ! 'from her husband, of course' $\left[\left\{(\text { de son mari })_{\mathrm{AP}}\right\}_{\text {ip }}\left\{(\text { pardi })_{\mathrm{AP}}\right\}_{\text {ip }}\right]_{\mathrm{IP}}$ 
b. A: Qu'est ce que vous voulez ?

'What would you like?'

B: je voudrais des oranges, s'il vous plait madame.

$\left[\left\{(\mathrm{je} \text { voudrais })_{\mathrm{AP}} \text { (des oranges }\right)_{\mathrm{AP}}\right\}_{\text {ip }} \quad\left\{\left(\mathrm{s}^{\prime} \mathrm{il}\right.\right.$ vous plait $\left.\left.)_{\mathrm{AP}}(\text { madame })_{\mathrm{AP}}\right\}_{\mathrm{ip}}\right]_{\mathrm{IP}}$

'I want some oranges, please, Madam'

c. A: Vous voulez des citrons?

'Do you want some lemons?'

B: Non, ce sont des oranges que je veux

$[\text { non }]_{I P}\left[\left\{(\text { ce sont des oranges })_{\mathrm{AP}}\right\}_{\mathrm{ip}}\{(q u e\right.$ je veux $\left.\left.)_{\mathrm{AP}}\right\}_{\text {ip }}\right]_{\mathrm{IP}}$

'No, it is some oranges that I want.'

The ip boundaries after mari (7a), and oranges (7b and 7c) are aligned with the right edge of the focus constituent (i.e. the elliptical answer or the focus NP), as these elements constitute the answer to the question. In some accounts, an IP rather than an ip boundary is located in these positions, mostly because of the intonational contours associated with these boundaries (see, among others, [15], [19] and [20]). In any case, it is clear that the initial part analysed as forming an ip encompass the informational focus associated with the utterance, while what follows is not crucial informationally and could be considered as a tail.

\section{Tonal patterns and intermediate phrase}

In section 2, three distinct types of $i p$ were proposed on the basis of the boundary position. In this section, we will now focus on the tonal patterns associated with ip boundaries. Before we do so, some characteristics of French intonation will be presented.

\subsection{Tonal inventory in French}

French is characterized by a succession of contours that occur at the end of prosodic phrases. These contours are mostly rising in cases of non-final constituents, regardless of the level of structure (i.e $\mathrm{LH}^{*}$ for Accentual Phrases, $\mathrm{LH}^{*} \mathrm{H}-$ for intermediate phrases, and $\mathrm{LH}^{*} \mathrm{H} \%$ for Intonational Phrases, see among others [6], [8], [21] and [22]). By contrast, a greater variety of tonal contours can occur in sentence final position, or at the end of the prosodic phrase that contains the informational focus constituent ([6], [8], [19] and [21]).

Table 1: Inventory of terminal and non terminal contours in French

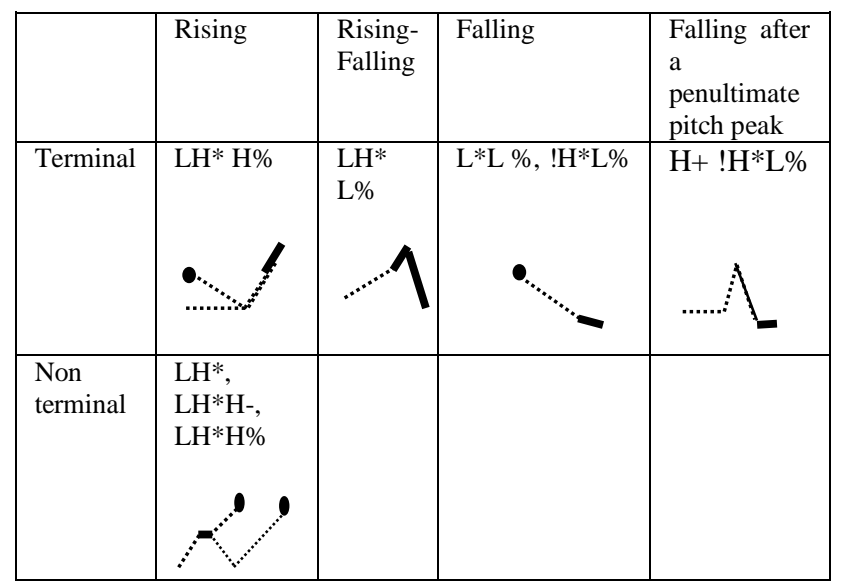

In many works devoted to the intonation of French, a distinction is generally proposed between two categories of tonal contours: terminal and non-terminal contours, ([6], [8], [15], for examples). In [15], next to Ci contours whose form is determined by sentence modality (question vs. assertion), there are contours whose form depends on their linear position and the degree of embedding. In [6], but also in [8] and [21], a distinction is made between terminal and non-terminal contours, the inventory of non-terminal contours being more limited, as shown in Table 1.

\subsection{Tonal contour at the end of the intermediate phrase}

According to the Table 1, rising contours are usually observed at the end of non-terminal accentual and intermediate phrases. This generalization is confirmed by the analyses presented in [8] and [9]. In most of the given examples, a rising tonal contour is obtained at the end of non-final $i p$, either when the right boundary aligned with the right edge of a long NP subject as in (4) or when it occurs at the end of a topic phrase as in (9) with a dislocated structure (see Figure 1).

(9) Les amis du mari de Valérie, je les ai appelés.

$\left[\left\{(\text { les amis })_{\mathrm{AP}}(\mathrm{du} \text { mari })_{\mathrm{AP}}(\text { de Valérie })_{\mathrm{AP}}\right\}_{\text {ip }}\{(\right.$ je les ai appelés $\left.\left.)_{\mathrm{AP}}\right\}_{\mathrm{ip}}\right]_{\mathrm{IP}}$

'the friends of Valerie's husband, I rang them'

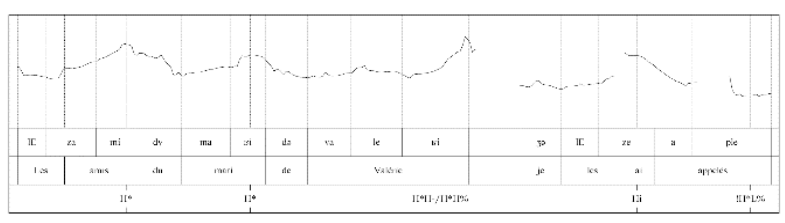

Figure 1: f0 curve of sentence in (9)

Non-rising tonal contours are almost exclusively observed in cases where the $i p$ boundary coincides with the right edge of the focal domain. In all the examples from [8] cited in (7) above, we observed a rising-falling $\left(\mathrm{H}+\mathrm{H}^{*} \mathrm{~L}-\right)$ in $7 \mathrm{a}$ and a falling one (encoded ! $\mathrm{H}^{*} \mathrm{~L}-$ or $\mathrm{L} * \mathrm{~L}-$ ) in $7 \mathrm{~b}$ and $7 \mathrm{c}$. Interestingly, the form of these contours matches what has been identified as terminal contour in the literature, see (8) and [6] among others. The sequence after the ip boundary is usually pronounced with a relatively flat intonation similar to what is observed in tails (see, among others, [21] and [23]).

Following these realizations, a distinction can be made between metrically-driven and incidental ips on the one hand, and $i p$ boundaries aligned with the edge of a focus domain on the other. Based on the type of tonal patterns observed at the end of focal domains, the $i p$ boundary in the cases in (7) should be treated as a terminal boundary, and hence, as an IP boundary. This is what we will argue in the section 4 .

\subsection{Tonal realization: from phonology to phonetic implementation}

As previously said, a rising contour is usually observed at the end of the metrically-driven ip and the incidental ip. In some cases, however, falling tonal contours occur at the end of these sentence-internal ips. An analysis of these falling cases reveals that a distinction has to be made between metrically-driven and the incidental ips.

In (9), a rising contour $\mathrm{LH}^{*} \mathrm{H}$ - is realized at the edge of the incidental ip that coincides with the dislocated NP les amis $d u$ mari de Valérie, as shown in Figure 1, and the entire sentence ends with a falling contour ! $\mathrm{H}^{*} \mathrm{~L} \%$. When the clause to which 
the Topic phrase (TopP) depends is right-headed by a rising contour $\mathrm{H}^{*} \mathrm{H} \%$ as in (10) and (11), the contour at the end of the incidental ip, by contrast, is usually falling (see fig 2 , and also fig. 3.7 in [8]), the F0 drop being sometime realized late (see Figure 2).

(10) Les amis du mari de Valérie, vous les avez appelés? $\left[\left\{(\text { les amis })_{\mathrm{AP}}(\text { du mari })_{\mathrm{AP}}(\text { de Valérie })_{\mathrm{AP}} \searrow\right\}_{\text {ip }}\{\ldots \ldots . . .\}_{\text {ip }}\right]_{\mathrm{IP}}$ 'the friends of Valerie's husband, did you ring them ?'

(11) Les amis du mari de Valérie, je les ai appelés et nous nous sommes rencontrés (Fig. 2).

$\left[\left\{(\text { les amis })_{\mathrm{AP}}(\text { du mari })_{\mathrm{AP}}(\text { de Valérie })_{\mathrm{AP}} \searrow\right\}_{\text {ip }}\{\right.$ (je les ai appelés $\left.\left.)_{\mathrm{AP}}\right\}_{\mathrm{ip}}\right]_{\mathrm{IP}}[\text { [...et nous nous sommes rencontrés.. }]_{\mathrm{IP}}$ 'the friends of Valerie's husband, I rang them, and we met'

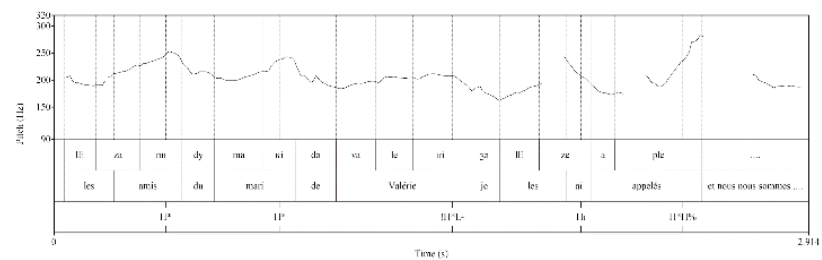

Figure 2: f0 curve of sentence in (11)

The falling realization of a continuation as observed in (10) and (11) has been mentioned by [15] and [21]. [15] argued that such a realization is motivated by the need to highlight the contrast between this continuation (called minor continuation by [21]) and the rising tonal movement occurring at the end of a question or a non-final clause in case of clause chaining.

Interestingly, such a falling realization is almost never observed in the case of metrically-driven ips. When a long NP subject is realized in a non-terminal clause or in a declarative question as in (12), the rising tonal pattern expected at its right edge is not as clearly realized because of a speech rate increase (see fig. 3). Note however that no late drop occurs at the ip boundary by contrast with what happens in (10) and (11), see. Figure 2.

(12) Les amis du mari de Valérie m'ont appelé et nous nous sommes rencontrés.

[\{(les amis)AP(du mari)AP (de Valérie)AP $\}$ ip \{(m’ont appelé)AP \}ip]IP [...et nous nous sommes rencontrés..]IP

'the friends of Valerie's husband, I rang them, and we met'

The changes that appear in the way to implement the contour associated with the last syllables of the metricallydriven ip in utterances like (12) are comparable to what was observed by [9] when speakers were asked to speak faster. This also fits with the analysis from [6], showing that total or partial deaccenting may occur at the level of the phonological phrase. These phenomena argue for the metrical status of this $i p$, and for an analysis of the tonal pattern occurring at the edge of such an ip in terms of phrasal accent.

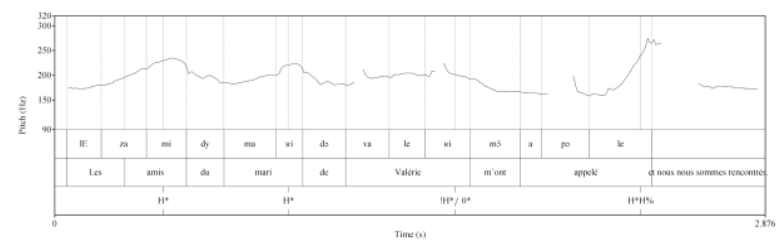

Figure 3: f0 curve of sentence in (12)

\section{Proposal and Conclusion}

The differences in the distribution and possible tonal patterns associated with ip boundaries argue for a distinction between the three types of $i p$ mentioned in section 2.

Since tonal patterns and phenomena are observed at the right edges of the intermediate phrases associated with independent clauses or focal domain on the one hand, and with the incidental ip on the other, we consider these two types of intermediate phrase as IPs. In order to account for the distinction between these two prosodic phrases with respect to the types of tonal patterns observed at their right edge (terminal $v s$. non-terminal contour), we argue for two types of IP: (i) the Major-IP that corresponds to independent clauses or elliptical sequences containing the informational focus; and (ii) the Minor-IP whose right edge coincide with the right edge of commaP or Topic Phrase. Terminal contours (see (8)) will be realized at the end of Major-IPs, and will be copied at the end of the independent clause as in (7b) repeated in (13), forming a recursive structure.

(13) $\left[\left[(\text { je voudrais })_{\mathrm{AP}}(\text { des oranges })_{\mathrm{AP}}\right]_{\mathrm{Major}-\mathrm{IP}}(\mathrm{s} \text { 'il vous plait })_{\mathrm{AP}}\right.$ (madame) $\left.)_{\mathrm{AP}}\right]_{\text {Copied-Major-IP }}$

As for the Minor-IP, they will be right-headed by a tonal contour whose form is partially determined by the form of the terminal contour, even if the rising pattern is the default. These IPs enter in a recursive structure with Major-IP, as shown in (14a and b) equivalent respectively to (9) and (11).

(14) a. [[(les amis $\left.)_{\mathrm{AP}}(\text { du mari })_{\mathrm{AP}}(\text { de Valérie) })_{\mathrm{AP}}\right]_{\text {Minor-IP }}$ (je les ai appelés $\left.)_{\mathrm{AP}}\right]_{\text {Major-IP }}$

b. $\left[\left[(\text { les amis })_{\mathrm{AP}}(\mathrm{du} \text { mari })_{\mathrm{AP}}(\text { de Valérie })_{\mathrm{AP}} \searrow\right]_{\mathrm{Minor}-\mathrm{IP}}[(\mathrm{je}\right.$ les ai appelés $\left.)_{\mathrm{AP}}\right]_{\text {Major-IP }}$ [...et nous nous sommes rencontrés... Major-IP

IPs derived from Topic and Adjunct phrases may be analysed as a recursive sub-category of IPs derived from true independent clauses, drawing a parallel to what was proposed by [24] for distinguishing Minor Phrase from Major Phrase However, further research is necessary in the case of parentheticals.

In contradistinction to the ips analysed as IPs, metricallydriven $i p$ s remain $i p s$, but a parallel between this unit and phonological phrases can easily be made. APs and ips could thus be seen as metrical units, equivalent to minor and major phonological phrases respectively (see [4], [5]). Because of the syncretism between intonation and accentuation in French, tonal events occur at the edge of this unit, but they can be considered as reflecting a phrasal accent. Arguments in favour of such an analysis are twofold: the lack of falling realization for the tonal patterns, and limitations on possible restructuring.

Further research is now necessary to validate this analysis on large scale data and through experimental studies.

\section{Acknowledgements}

This work is supported/ partially supported by a public grant overseen by the French National Research Agency (ANR) as part of the program "Investissements d'Avenir" (reference: ANR-10-LABX-0083). It contributes to the IdEx Universite de Paris - ANR-18-IDEX-0001. 


\section{References}

[1] R. D. Ladd, Intonational Phonology, $2^{\text {nd }}$ ed, CUP, 2008.

[2] J. Pierrehumbert, \& M. Beckman, Japanese Tone Structure, MIT Press, 1988.

[3] M. Nespor, \& I. Vogel, Prosodic Phonology, Mouton de Gruyter, (1986: Foris), 1986/2007.

[4] E. Selkirk, "On derived domains in sentence phonology", Phonology 3: 371-405, 1986.

[5] E. Selkirk, "The syntax-phonology interface", in J. Goldsmith, J. Riggle and A. Yu [Eds], The Handbook of Phonological Theory, 435-484, 2nd edition, Blackwell, 2011

[6] B. Post, Tonal and Phrasal Structures in French Intonation. PhD Dissertation. Holland Academic Graphics, The Hague, 2000.

[7] S.A. Jun \& C. Fougeron. A phonological model of French Intonation. In Intonation: Models, analysis and applications. Cambridge University Press, Cambridge, pages 209-242, 2000.

[8] E. Delais-Roussarie, , B. Post, M. Avanzi, C. Buthke, A. D Cristo, I. Feldhausen, S.-A. Jun, P. Martin, T. Meisenburg, A. Rialland, R. Sichel-Bazin, \& H.-Y. Yoo, , "Developing a ToBI system for French", in S. Frota and P. Prieto [Eds], Intonational Variation in Romance, chapter 3, Oxford University Press, 2016.

[9] A. Michelas, Caractérisation phonétique et phonologique du syntagme intermédiaire en français: de la production à la perception, Thèse de doctorat d'Aix-Marseille Université, 2011

[10] E. Delais-Roussarie. Phonological Phrasing and Accentuation in French. In Dam Phonology: HIL phonology papers II. Holland Academic Graphics, The Hague, pages 1-38, 1996

[11] I. Feldhausen, Sentential Form and Prosodic Structure of Catalan, John Benjamins, 2010

[12] E. Selkirk, "The Interaction of Constraints on Prosodic Phrasing", in M. Horne [Ed], Prosody: Theory and Experiment, 231-261, Kluwer Academic Press, 2000.

[13] S.-A. Jun, S.-A. \& H.-J. Lee, "Phonetic and Phonological markers of Contrastive Focus in Korean", in Proceedings of the 5th ICSLP, 4:1295-1298, 1998

[14] C. Fery, "Focus and Phrasing in French". In Caroline Féry and Wolfgang Sternefeld (eds), Audiatur Vox Sapientiae. A Festschrift for Arnim von Stechow, 153-181. Berlin. AkademieVerlag, 2001.

[15] P. Martin. Prosodic and rhythmic structures in French Linguistics, 25: 925-949, 1987.

[16] E. Delais-Roussarie, \& I. Feldhausen "Variation in Boundary Strength in French." In Proceedings of Speech Prosody 2014. Dublin, May 2014, 2014.

[17] M. Avanzi, "La dislocation à gauche en français parlé. Etude instrumentale", Le français moderne, 2011(2), 2012

[18] P. Mertens, "Syntaxe, Prosodie et structure informationnelle: une approche prédictive pour l'analyse de l'intonation dans le discours", Travaux de Linguistique, 56:97-124, 2008.

[19] E. Delais-Roussarie, \& B. Post, "Unités prosodiques et grammaire de l'intonation : vers une nouvelle approche", Actes des Journées d'étude sur la Parole JEP-TALN, 2008

[20] E. Delais-Roussarie \& A. Rialland. Metrical organization, tonal association and focus in French. In S. Blaauw et F. Drijkoningen (eds.) Romance languages and linguistic theory 2005. John Benjamins Publishing, pages 73-98. 2005.

[21] P. Delattre. Les dix intonation de base du français. The French Review 40 (1), pages 1-14, 1966.

[22] S.-A. Jun \& C. Fougeron. A phonological model of French Intonation. In Intonation: Models, analysis and applications. Cambridge University Press, Cambridge, pages 209-242, 2000.

[23] P. Wunderli, L'intonation des séquences extraposées en Français. Gunter Narr Verlag, 1987.

[24] J. Ito \& A. Mester, Prosodic Subcategories in Japanese. Lingua 124. 20-40. 2013. 